\title{
THE JOURNAL OF ECOLOGY
}

\author{
Editors: P. J. GRUBB, C. H. GIMINGHAM and J. H. TALLIS
}

Vol. 64 , No. 2

JULY 1976

D. W. H. Walton. Dry matter production in Acaena (Rosaceae) on a subantarctic island.

László Orlóci. Ranking species by an information criterion.

Bruce E. Mahall and Roderick B. Park. The ecotone between Spartina foliosa Trin. and Salicornia virginica L. in salt marshes of northern San Francisco Bay. I. Biomass and production.

David J. Parsons. Vegetation structure in the Mediterranean scrub communities of California and Chile.

M. S. Rahman. A comparison of the ecology of Deschampsia caespitosa (L.) Beauv. and Dactylis glomerata L. in relation to the water factor. I. Studies in field conditions.

D. H. Ashton. The vegetation of Mt Piper, Central Victoria: a study of a continuum.

J. R. Packham and A. J. Willis. Aspects of the ecological amplitude of two woodland herbs, Oxalis acetosella $\mathrm{L}$. and Galeobdolon luteum Huds.

Wayne R. Hawthorn and Paul B. Cavers. Population dynamics of the perennial herbs Plantago major $\mathrm{L}$. and $P$. rugelii Decne.

C. S. Reynolds. Succession and vertical distribution of phytoplankton in response to thermal stratification in a lowland mere, with special reference to nutrient availability.

R. D. Kelly and B. H. Walker. The effects of different forms of land use on the ecology of a semiarid region in south-eastern Rhodesia.

C. G. Trapnell, M. T. Friend, G. T. Chamberlain and H. F. Birch. The effects of fire and termites on a Zambian woodland soil.

T. C. E. Wells, J. Sheail, D. F. Ball and L. K. Ward. Ecological studies on the Porton Ranges: relationships between vegetation, soils and land-use history.

G. S. Hope. The vegetational history of Mt Wilhelm, New Guinea.

S. J. J. F. Davies. Studies of the flowering season and fruit production of some arid zone shrubs and trees in Western Australia.

Richard I. Yeaton and Martin L. Cody. Competition and spacing in plant communities: the northern Mohave Desert.

J. E. Ash and J. P. Barkham. Changes and variability in the field layer of a coppiced woodland, Norfolk, England.

M. A. Ayyad. Vegetation and environment of the western Mediterranean coastal land of Egypt. IV. The habitat of non-saline depressions.

M. J. Hutchings and J. P. Barkham. An investigation of shoot interactions in Mercurialis perennis L., a rhizomatous perennial herb.

M. J. M. Oomes and W. Th. Elberse. Germination of six grassland herbs in microsites with different water contents.

BIOLOGICAL FLORA OF THE BRITISH ISLES

T. C. E. Wells. Hypochoeris Maculata L.

Reviews

Subscription price $\$ 30.00$ per volume of three parts

BLACKWELL SCIENTIFIC PUBLICATIONS LTD

OSNEY MEAD - OXFORD 


\title{
THE JOURNAL OF ANIMAL ECOLOGY
}

\author{
EDITORS: L. R. TAYLOR and J. M. ELLIOTT
}

VOL. 45, No. 2

JUNE 1976

A. J. Gaston. Brood parasitism by the Pied Crested Cuckoo Clamator jacobinus.

Larry L. Wolf, F. Gary Stiles and F. Reed Hainsworth. Ecological organization of a tropical, highland hummingbird community.

David Wool. Changes of life-history stage distribution of single strain and mixed Tribolium populations during a single generation at a lowered temperature (Coleoptera: Tenebrionidae).

Raymond Hewson. A population study of mountain hares (Lepus timidus) in north-east Scotland from 1956-1969.

B. E. Freeman and K. Ittyeipe. Field studies on the cumulative response of Melittobia sp. (Hawaiiensis complex) (Eulophidae) to varying host densities.

Walter Leuthold. Group size in elephants of Tsavo National Park and possible factors influencing it.

Michael Begon. Dispersal, density and microdistribution in Drosophila subobscura Collin.

Ronald W. Davies and Trefor B. Reynoldson. A comparison of the life-cycle of Helobdella stagnalis (Linn. 1758) (Hirudinoidea) in two different geographical areas in Canada.

M. P. Hassell, J. H. Lawton and R. M. May. Patterns of dynamical behaviour in single-species populations.

K. D. Sunderland, Mark Hassall and S. L. Sutton. The population dynamics of Philoscia muscorum (Crustacea, Oniscoidea) in a dune grassland ecosystem.

G. M. Branch. Interspecific competition experienced by South African Patella species.

J. W. F. Davis. Breeding success and experience in the arctic skua Stercorarius parasiticus (L.).

Malte Andersson. Population ecology of the long-tailed skua (Stercorarius longicaudus Vieill.).

J. M. Elliott. Energy losses in the waste products of brown trout (Salmo trutta L.).

Maurice A. Lock and T. B. Reynoldson. The role of interspecific competition in the distribution of two stream dwelling triclads, Crenobia alpina (Dana) and Polycelis felina (Dalyell), in North Wales.

A. F. G. Dixon. Timing of egg hatch and viability of the sycamore aphid, Drepanosiphum platanoidis (Schr.), at bud burst of sycamore, Acer pseudoplatanus $\mathrm{L}$.

Reviews

Subscription price $£ 30.00$ per volume of three parts

BLACKWELL SCIENTIFIC PUBLICATIONS LTD OSNEY MEAD - OXFORD 


\section{THE MARINE BIOLOGICAL ASSOCIATION OF THE UNITED KINGDOM}

ThE Association was founded in 1884 to promote accurate researches leading to the advancement of zoological and botanical science and to an increase in our knowledge of the food, life, conditions and habits of British fishes. The work of the Association is controlled by a Council elected annually by its subscribing members.

Professor T. H. Huxley took the chair at the initial meeting held in the rooms of the Royal Society and was elected the first President. Among those present were Sir John Lubbock (afterwards Lord Avebury), Sir Joseph Hooker, Professor H. N. Moseley, Mr G. J. Romanes, and Sir E. Ray Lankester who, after Professor Huxley, was for many years president of the Association. It was decided to build a laboratory at Plymouth, where a rich and varied fauna is found.

The Plymouth Laboratory was opened in June 1888, and, since that date, considerable additions have been made to the buildings, including a library, lecture-hall, and extensive laboratory accommodation with up to-date equipment. Additional sea-water reservoirs have also been built, and an aquarium, modernized in 1959, opened to the public.

Since its foundation the Association has been supported by subscriptions and donations from private members, universities, learned societies, the Fishmongers' Company and other public bodies. For some time past, however, the main financial support for the work of the Plymouth Laboratory has come from Government funds, and since 1965 the Laboratory has been grant-aided through the Natural Environment Research Council.

The Marine Biological Association, under the direction of its Council, undertakes research in all branches of marine science and the main results are published in this journal. Accounts of the laboratory and aquarium are to be found in Vol. 27 (p. 761), Vol. 39 (p. 391) and Vol. 43 (p. 281), and summaries of the activities and research of the Association are given annually in the Report of the Council in the November issue of the Journal.

The laboratory is open throughout the year and its work is carried out by a fully qualified research staff under the supervision of the Director. The names of the members of the staff will be found on the inner page of the front cover. Accommodation is available for British and foreign scientific workers who wish to carry out independent research in all branches of marine science. Arrangements are made for courses for advanced students, and marine animals and plants are supplied to educational institutions.

Work at sea is undertaken by three research vessels and by a motor boat, and these also collect the specimens required in the laboratory.

\section{TERMS OF MEMBERSHIP}

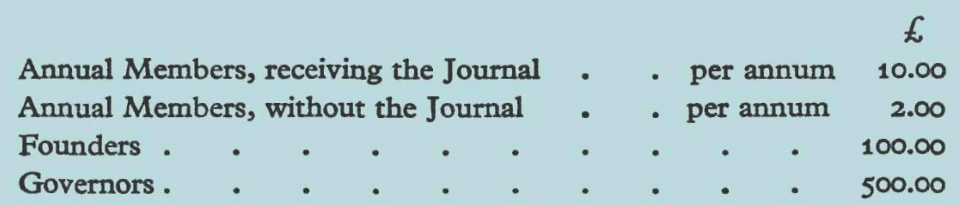

Members of the Association have the following rights and privileges: they elect annually the Officers and Council; they are entitled to receive the Journal of the Association at a reduced rate; they are admitted to view the laboratory at Plymouth; they have the first claim to rent a place in the laboratory for research, with use of tanks, boats, etc; they have the privilege of occupying a table for one week in each year free of charge; and they have access to the books in the library at Plymouth during working hours.

The Commissioners of Inland Revenue have approved the Association for the purposes of Section 16, Finance Act, 1958, and that the whole of the annual subscription paid by a member who qualifies for relief under the section will be allowable as a deduction from his emoluments assessable to income tax under Schedule E.

All correspondence should be addressed to the Director, The Laboratory, Citadel Hill, Plymouth, PL1 2PB. 


\section{CONTENTS}

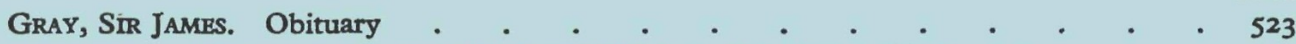

PARKE, M. and DIXON, P. S. Check-list of British marine algae - third revision . . . 527

GreEN, J. C. Notes on the flagellar apparatus and taxonomy of Pavlova mesolychnon Van der Veer, and on the status of Pavlova Butcher and related genera within the Haptophyceae

KAIN, J. M. (MRS N. S. JONES). The biology of Laminaria hyperborea. IX. Growth patterns of fronds

Berland, B. R., Bonin, D. J., Maestrint, S. Y., LizÁrraga-Partida, M. L. and Antia, N.J. The nitrogen concentration requirement of D-glucosamine for supporting effective growth of marine microalgae .

Binyon, J. The permeability of the asteroid podial wall to water and potassium ions .

GIBSON, P.H. and ClARK, R.B. Reproduction of Dodecaceria caulleryi (Polychaeta: Cirratulidae)

HARRIS, R. P. and PAFFENhörER, G.-A. Feeding, growth and reproduction of the marine planktonic copepod Temora longicornis Müller

LEMCHE, H. New British species of Doto Oken, 1815 (Mollusca: Opisthobranchia) . .

GIRSCH, S. J., HerRING, P. J. and MCCAPRA, F. Structure and preliminary biochemical characterization of the bioluminescent system of Ommastrephes pteropus (Steenstrup) (Mollusca: Cephalopoda) . . . . . . . . . . . 707

LUTZ, R. A. Annual growth patterns in the inner shell layer of Mytilus edulis L. . . $\quad 723$

CLARKE, M. R. and MACLEOD, N. Cephalopod remains from sperm whales caught off Iceland 733

MACKIE, G. O. and BONE, Q. Skin impulses and locomotion in an ascidian tadpole . . $\quad 751$

Wirson, K. W. and ConNor, P. M. The effect of china clay on the fish of St Austell and

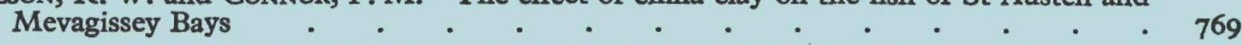

MöLLER, H. Reduction of the intestinal parasite fauna of marine fishes in captivity . $\quad$. $\quad 781$

DeNTON, E. J. and BLAXTER, J. H. S. The mechanical relationships between the clupeid swimbladder, inner ear and lateral line $. \quad . \quad . \quad . \quad \cdot \quad . \quad \cdot \quad \cdot 787$

SHORT NOTES

ANNOUNCEMENT .

ABSTRACTS OF MEMOIRS

BOoK Notices

C Copyright by the Marine Biological Association of the U.K. 1976

The subscription price of volume 56,1976 of the Journal to non-members of the Association is $£ 38.00$ net a volume of four parts, post free, or US $\$ 105.00$ in U.S.A. and Canada, payable in advance. Subscriptions may be sent to any bookseller or to the London or New York office of Cambridge University Press.

\section{CAMBRIDGE UNIVERSITY PRESS \\ BENTLEY HOUSE, 200 EUSTON ROAD, LONDON NW1 2DB}

32 EAST 57TH STREET, NEW YORK, N.Y. 10022

Printed in Great Britain at the University Printing House, Cambridge 